\title{
バイオ医薬品の開発を支える分析技術の最新動向
}

\author{
石井明子, $*, a$ 内山 進 $b, c$

\section{Current Trends in Analytical Technologies Which Promote the Development of Biopharmaceuticals}

\begin{abstract}
Akiko Ishii-Watabe*,a and Susumu Uchiyama ${ }^{b, c}$
${ }^{a}$ Division of Biological Chemistry and Biologicals, National Institute of Health Sciences; 3-25-26 Tonomachi, Kawasaki-ku, Kawasaki 210-9501, Japan: 'bepartment of Biotechnology, Graduate School of Engineering, Osaka University; GSE East 7F, 2-1 Yamadaoka, Suita, Osaka 565-0871, Japan: and Exploratory Research Center on Life and Living Systems, National Institutes of Natural Sciences; 5-1 Higashiyama, Myodaiji-cho, Okazaki, Aichi 444-8787, Japan.
\end{abstract}

抗体医薬品を始めとするバイオ医薬品は，がんや 免疫系疾患等の治療に不可欠な存在となり，アン メットメディカルニーズを満たす新たなバイオ医薬 品開発への期待も，これまでになく高まっている. 近年, ヒトタンパク質の構造を高度に改変したバイ 才医薬品の開発が増えていることや，安全性との関 連が懸念される不純物の存在が指摘されていること 等から, 開発候補分子の探索から市販後の品質管理 戦略の様々な段階で，先端的な分析技術を用いた品 質評価の重要性が増している。本シンポジウムで は, バイオ医薬品の分析に関する最先端の研究を 行っている産学官の研究者を演者に迎え, 糖鎖, 高 次構造, 凝集体等の分析に関する研究のほか, バイ 才医薬品の自社開発を進めている製薬企業における 分析技術の最新動向について講演頂いた.

最初の演者として, 中外製薬工業の齋藤 智博士 からは「抗体医薬品開発における重要品質特性 (critical quality attribute; CQA) の特定」について ご講演頂いた. ICH Q8（R2）で述べられているよ うに，医薬品は患者のニーズ及び意図された製品の 機能を満たすように設計されるべきである. CQAs の特定は，科学とリスクに基づく製品開発の体系的

${ }^{a}$ 国立医薬品食品衛生研究所生物薬品部 ( $\overline{2} 210-9501$ 川崎市川崎区殿町 3-25-26), ${ }^{b}$ 大阪大学大学院工学研 究科生命先端工学専攻 (T565-0871 大阪府吹田市山田 丘 2-1 GSE イースト 7F), ${ }^{c}$ 自然科学研究機構生命創 成探究センター（テ444-8787 愛知県岡崎市明大寺町字 東山 5-1)

*e-mail: watabe@ @ihs.go.jp

日本薬学会第 137 年会シンポジウム S 58 序文
な手法である quality by design (QbD) アプローチ において，最初の重要なステップである。各 potential CQAs のインパクトは, Bioactivity, Pharmacokinetics/Pharmacodynamics, Immunogenicity 及び Safety の観点で体系的かつリスクベースアプ ローチによって評価される。ご講演では, 抗体医薬 品を始めとするバイオ医薬品の品質評価において用 いられている CQAs の特定方法及びそのための新 しい分析技術の例をご紹介頂き， $\mathrm{QbD}$ アプローチ を活用した品質管理戦略構築に関する考え方につい て議論した。

国立医薬品食品衛生研究所の橋井則貴博士からは 「質量分析による $\mathrm{Fc}$ 融合タンパク質医薬品の $O$-結 合型糖鎖部位特異的解析」についてご講演頂いた. 近年, 生理活性ペプチドやレセプタータンパク質等 と $\mathrm{IgG}$ の $\mathrm{Fc}$ 部分を融合した Fc 融合タンパク質の 開発品目が増加している。 Fc 融合タンパク質で は，各ドメインをつなぐためにペプチドリンカーが 用いられることがあるが，近年， $\mathrm{CHO}$ 細胞発現系 により産生された Fc 融合タンパク質において, 生 理活性ペプチド配列やペプチドリンカー配列上に,

$O$-結合型糖鎖が付加されていた例が報告されてい る.このような $O$-結合型糖鎖がタンパク質の機能 に影響を及ぼす事例も見い出されていることから，

$\mathrm{Fc}$ 融合タンパク質などの非天然型構造を有するバ イオ医薬品では，意図しない $O$-結合型修飾が生じ る可能性を考慮し, 開発過程で詳細な $O$-結合型糖 鎖解析を行うことが重要となっている. 講演では, 糖ペプチドのペプチド部分を優先して解離させるこ 
とが可能な電子移動解離 (electron-transfer dissociation；ETD）法等を利用した質量分析により，Fc 融合タンパク質医薬品の $O$-結合型糖鎖部位特異性 解析を実施した結果を紹介して頂き，質量分析を用 いた翻訳後修飾の分析法の有用性を議論した.

名古屋市立大学 /自然科学研究機構生命創成探求 センターの加藤晃一博士からは「バイオ医薬品への 構造生物学的アプローチ」について講演頂いた。バ イオ医薬品の研究開発において，分子構造の詳細を 把握することは重要であり, X 線結晶構造解析や 核磁気共鳴法（NMR）を用いて得られる 3 次元構 造情報は新たな分子デザインの基盤を与える。しか し，バイオ医薬品の構造解析においては，糖鎖修飾 を始めとする多様な翻訳後修飾がもたらす分子構造 の複雑性が問題となり，糖鎖を含めたタンパク質の 立体構造情報の蓄積は著しく立ち遅れているのが現 状である．また，バイオ医薬品は特異的な分子間相 互作用を通じてその機能を発揮しているが，生体内 での複雑な環境を考慮した解析はほとんど行われて こなかった。講演では，バイオ医薬品が実際に機能 する環境を考慮した新たな評価手法として，NMR を用いた血清中での抗体の高次構造と相互作用を解 析した結果をご紹介頂き，バイオ医薬品の開発にお ける有用性と期待について議論した。

協和発酵キリンの湊 雄一博士からは「バイオ医 薬品の高次構造評価」について講演頂いた。組換え 体細胞等のタンパク質発現系から産生されるバイオ 医薬品では, 翻訳後修飾等による分子構造上の不均 一性が生じ，翻訳後修飾を含む様々な要因により高 次構造にも変動が生じる可能性がある。そのため, 製品の有効性及び安全性に影響する要因を特定する 手段の 1 つとして，また，バイオ医薬品の製法変更 に伴う同等性／同質性評価やバイオシミラーと先行 品の同等性／同質性評価において，高次構造の評価 は不可欠である。しかしながら，円偏光二色性 （circular dichroism; CD）や蛍光分光法等の既存の 評価系では，アミノ酸残基レベルでの高次構造変化 を検出できず，部位特異的な構造情報を取得するこ とは困難であった。講演では，水素／重水素交換一 質量分析 (hydrogen/deuterium exchange mass spec-
trometry；HDX-MS）によりアミノ酸残基レベルの 構造変化を検出する解析手法についてご紹介頂き, バイオ医薬品の高次構造評価において部位特異的な 構造情報を取得する有用性について議論した。

最後に, 大阪大学大学院 /自然科学研究機構生命 創成探求センターの内山から「バイオ医薬品に含ま れる凝集体の適切な分析に向けて」について講演し た。 バイオ医薬品は液剤として製剤化されるケース が多いが，製造や保管中に振とうや攪汼，プレフィ ルドシリンジであればシリコンオイルとの接触，な どのストレスを受け，有効成分であるタンパク質が 凝集体を形成する。凝集体は，数十 $\mathrm{nm}$ から数百 $\mu \mathrm{m}$ にいたる幅広いサイズ分布を持つが，なかでも $100 \mathrm{~nm}$ 以下のナノ粒子と $100 \mathrm{~nm}$ から $100 \mu \mathrm{m}$ の subvisible particles（SVP）は，免疫原性との関係 から, 近年, キャラクタリゼーション法の確立を目 指して, 精力的な研究が行われてきた. 現在では, 従来は難しかったサイズ領域を含め，幅広いサイズ の凝集体について評価可能な適切な分析手法が確立 しつつある. 講演では, タンパク質凝集体の物理化 学的特性の紹介の後, 凝集体の評価に利用される各 手法の特徵と役割を実際の測定例を交えながら説明 し，バイオ医薬の凝集体評価の今後の展望，につい ても述べた.

本誌上シンポジウムは，薬学会シンポジウムで発 表された各研究成果をより広い範囲で共有するた め, 各講演の概要を記録・公表するものである，近 年，日米欧各極で，革新的医薬品に関する優先審査 制度が設定され，日本でも先駆け審査制度が策定・ 運用されている。このようなケースでは，通常より 短期間での品質管理戦略構築が求められることか ら，これまでより一層の解析の迅速化と様々な知識 を活用した工夫が必要になるだろう。また，日本発 の優れた分析技術も開発されつつあり，世界をリー ドする高度な分析が期待されている状況にある. バ イオ医薬品の品質管理戦略構築に関する全体像とと もに，開発初期から承認製剤の出荷試験まで，バイ 才医薬品開発の様々な段階で活躍する先端的分析技 術の最新動向を提供した本誌上シンポジウムが，今 後のバイオ創薬推進の一助となれば幸いである. 